\title{
Beginning to Dismantle the Binaries that Frame the Neoliberal Kindergarten ${ }^{1}$
}

\author{
Christopher P. Brown \\ Correspondence: Christopher P. Brown, Department of Educational Leadership and Policy, The University of Texas at \\ Austin, 1912 Speedway, Stop D4700, Austin, TX 78712-1604, USA.
}

Received: April 5, 2021

doi:10.11114/jets.v9i5.5240

\author{
Accepted: May 16, $2021 \quad$ Online Published: May 18, 2021
}

URL: https://doi.org/10.11114/jets.v9i5.5240

\begin{abstract}
The binary logic of policymakers' neoliberal reforms has restructured kindergarten into a learning environment where teachers struggle to nurture children as learners. At the same time, the critiques that challenge these policies are also rooted in this binary logic. This allows policymakers' neoliberal reforms to remain intact. In this article, I address this issue through analysing findings from a larger research study that examined how a range of education stakeholders $(n=88)$ made sense of the changed kindergarten through binary logic. I then take apart these three binaries that emerged in my analysis process to provide insight into possible pathways for change that education stakeholders at all levels of governance can begin to engage in to dismantle policymakers' neoliberal education reforms.
\end{abstract}

Keywords: Kindergarten, binary logic, neoliberalism, education reform

\section{Introduction}

The narrative that kindergarten in the United States (US) is the new first grade is pervasive (Bassok, Latham, \& Rorem, 2016). Education researchers have documented how policymakers' neoliberal education reforms have turned kindergarten into a learning environment that privileges children's academic performance over their development and learning (Brown, Englehardt, Barry, \& Ku, 2019a; Graue, 2009). Many of these critiques, including my own with colleagues (e.g., Brown, Englehardt, Barry, \& Ku, 2019b), are rooted in a binary logic (e.g., ready vs. unready student) that positions the constructs defining public schooling, the act of teaching, the process of learning, families, and even the children themselves in opposition with each other (Mac Naughton, 2005). By accepting this binary logic without problematizing it, policymakers' neoliberal reforms remain intact (Dahlberg \& Moss, 2005).

Through analysing some the findings of a larger exploratory video-cued multivocal ethnographic (VCME) research study (Adair et al., 2018; Brown, 2021; Tobin et al., 2009) that shared a micro-level view of a day in a kindergarten classroom with a range of education stakeholders in Texas and West Virginia (e.g., Brown, Englehardt, Barry, \& Ku, 2019a), I examine how a sample of education stakeholders from these varied contexts appeared to use binary logic to make sense of the changed kindergarten. By doing so, I begin to pull apart some of these binaries that emerged in my analysis by employing Mac Naughton's (2005) and others (e.g., Foucault, 1982) tools for deconstruction.

\section{The Neoliberal Kindergarten}

Neoliberalism is a framing of governance rooted in economic principles that positions citizens as consumers (Apple, 2001). As I have argued elsewhere (e.g., Brown, 2015), policymakers across the globe seek to eliminate "(welfare) state services" while calling for increased "“personal responsibility' and 'self-care"” (Lemke 2001, p. 203). This leads to a framing of public education that "favours ... individual autonomy over citizen interdependence" (Clark \& Richards, 2017, p. 80). As such, policymakers have deemed the 'state' as a "regulator and auditor of the 'learning market"' (Biesta 2006, 175); public education systems are to provide citizens with the credentials needed to participate in the market (Ailwood, 2008). As I have noted before (e.g., Brown, Englehardt, Barry, \& Ku, 2019b), this is done through public school educators, including kindergarten teachers, providing children with the necessary "inputs" so that they can attain the required "outputs" on specific standardized achievement tests (Ball, 2007, p. 28).

Such policies have led to elementary and secondary teachers, including those in kindergarten, to spend more

\footnotetext{
${ }^{1}$ A version of this article was accepted but not presented at the canceled 2020 American Education Research Association Annual Conference.
} 
time on academic skills instruction and standardized assessments and less time on child-selected activities, music, and art (Bassok et al., 2016; Brown, 2021). Thus, by applying "the correct human technologies," kindergarten teachers are expected to produce "high returns" that lead to "improved education, employment and earnings and reduced social problems" of their students" (Moss, 2014, p. 3).

\subsection{Deconstructing the Neoliberal Kindergarten}

Mac Naughton (2005) employed Derrida's poststructural notion of deconstructivism to demonstrate how early educators can pull apart the language of early childhood texts to see how the meaning and language of practice is "contradictory, shifting, and incomplete" rather than fixed (p. 80). By doing so, Mac Naughton (2005) demonstrated how these texts establish hierarchies of meaning through binaries to establish cultural standards of normality. Through these binaries, the 'other' is produced - the 'other' being not equal to the main part of the pair (e.g., the 'unready' child) (p. 92). Mac Naughton's work helped illuminate how the ideas, concepts, or words used in early childhood education (ECE) - such as standards, accountability, and risk - are provisional, socially constructed, and can be dismantled, which creates new opportunities for stakeholders to rethink the purpose and process of schooling and what it means for a child to become educated.

In this article, I borrow from Mac Naughton's (2005) work and others (e.g., Kocher \& Pacini-Ketchabaw, 2011) to counter the binaries that many of the stakeholders in my study appeared to employ to make sense of the changed kindergarten. By investigating these hierarchies of meaning, which privilege policymaker's neoliberal reforms, I seek to "show how each term in the binary opposition is not in opposition but necessary to the other" so that I may dismantle the neoliberal logic and consider new conceptions of kindergarten specifically and schooling in general (Mac Naughton, 2005, p. 93).

\section{Methodology}

Through examining the findings from a larger exploratory VCME research study (Adair et al., 2018; Brown, 2021; Tobin et al., 2009) that sought to understand how a set of stakeholders in Texas $(n=62)$ and West Virginia $(n=26)$ made sense of the types of learning experiences kindergarteners are and should be having in school and why (Brown, Englehardt, Barry, \& Ku, 2019a; Brown, Englehardt, Barry, \& Ku, 2019b; Brown, Englehardt, Ku, \& Barry 2019c; Brown, Barry, Ku, \& Englehardt, 2021), I, in this article, seek to identify and dismantle some of the binaries that frame the changed kindergarten. I do so by examining the following research question: How did education stakeholders in this study appear to use binary logic, which privileges policymaker's neoliberal reforms, to make sense of the changed kindergarten? To be clear, my focus in this article is on kindergarten. Kindergarten has its own history (e.g., Dombkowski, 2001) that differs significantly from other early learning programs (Brown \& Barry, 2019), including elementary school (e.g., Adair et. al, 2018).

Texas (TX) and West Virginia (WV) were selected for the larger study because they differ in terms of region, population, and politics, and how they fund and educate their students (see Table 1 for a comparison between the two states).

Table 1. Differences between Texas and West Virginia Public Schools ${ }^{2}$

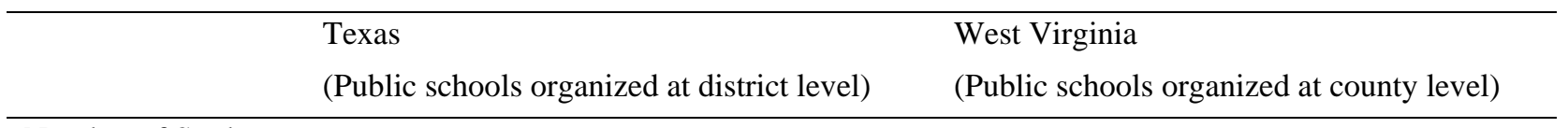

Number of Students

$5,359,127^{3} \quad 273,170$

Number of

Districts ${ }^{4}$ Counties

$1,232^{5}$

Per Pupil Spending

$(2016)^{6}$

$\$ 8,485$ per student

$\$ 12,993$ per student

\footnotetext{
2 This table is a modified version of a similar table found in Brown, Englehardt, Barry, and $\mathrm{Ku},(2019 \mathrm{a})$

${ }^{3} \mathrm{https}: / /$ tea.texas.gov/sites/default/files/enroll_2016-17.pdf

${ }^{4}$ West Virginia schools are organized by counties rather than districts

${ }^{5}$ From https://www.nationsreportcard.gov/data_tools.aspx

${ }^{6}$ From 2016 Annual Survey of School System Finances, U.S. Census Bureau
} 
Student-to-teacher ratio

Sociocultural
makeup of student
population

12.6\% African American

$4.2 \%$ Asian

$52.4 \%$ Hispanic

$28.1 \%$ White

$59 \%$ Economically disadvantaged

$18.9 \%$ English language learners

Compulsory School $\mathrm{Age}^{7}$

Common Core State Standards Initiative (CCSSI)

State

Accountability System

Kindergarten

Prekindergarten
State of Texas Assessment of Academic Readiness (STAAR) ${ }^{9}$ measures students' comprehension of the TEKS. Students in grades 3-8 are tested in mathematics and reading, grades 4 and 7 in writing, grades 5 and 8 in science, and grade 8 in social studies. Grades 5 and 8 are promotion grades and students must pass the $10^{\text {th }}$ grade test to graduate high school. ${ }^{10}$

Statewide full-day program

Half-day intervention program offered to four-year-old children who qualify based on the following criteria: limited-English proficiency, low income, having an active-duty military parent, homelessness, or in foster care
One aide is assigned to a kindergarten class if the class enrolment exceeds 10 students.

\section{3\% African American}

$0.7 \%$ Asian

\section{6\% Hispanic}

$90.4 \%$ White

$80 \%$ Economically disadvantaged

$1.0 \%$ English language learners

Age 6 by July 1 of that academic school year $^{8}$

Participant at time of this study; West Virginia formally withdrew from CCSSI in 2017, yet the current statewide College and Career Readiness Standards are modelled on the CCSSI blueprint

At the time of this study, West Virginia administered the West Virginia General Summative Assessment (WVGSA), which included English language arts/literacy (ELA) and mathematics in grades 3-11 and science in grades 5, 8 , and $10 .^{11}$

Statewide full-day program. ${ }^{12}$

Universal access to part-time program for all four-year-olds (by July 1), and three-year-olds with IEPs

30 minutes of mandated recess each day

Recess No mandate for recess

\subsection{Participants}

Following the practices of VCME research (Adair et al., 2018; Tobin et al., 2009), I first recruited stakeholders within the school district in which the video was made (see Table 2 for a list of participants), which included the classroom kindergarten teacher, the kindergarteners, kindergarten teachers across the school, as well as school and district administrators $(n=30)$.

\footnotetext{
${ }^{7}$ From National Center for Educational Statistics https://nces.ed.gov/programs/statereform/tab5_1.asp

8 WV Policy 2510 (https://wvde.state.wv.us/policies/)

${ }^{9}$ From Texas Education Agency https://tea.texas.gov/WorkArea/DownloadAsset.aspx?id=51539620927

${ }^{10}$ From Texas Education Agency http://tea.texas.gov/student.assessment/ssi/

11 From West Virginia Department of Education https://wvde.us/wp-ontent/uploads/2018/01/gensummassess_faqs.pdf

12 From West Virginia Early Learning Readiness: Kindergarten Resource Guide

(http://wvde.state.wv.us/oel/docs/workbook2.pdf)
} 
Table 2. The Participants ( $\mathrm{n}=88)$

\begin{tabular}{|c|c|}
\hline Texas Participants & West Virginia Participants \\
\hline Lucinda*, Kindergartener in Video & Ms. Johnson*, Parent of a kindergartener in in WV \\
\hline Willow*, Kindergartener in Video & School District 1 (WVSD1) \\
\hline Gretchen*, Kindergartener in Video & Ms. Carter*, Parent of a kindergartener in WVSD1 \\
\hline Davis*, Kindergartener in Video & Mr. Pratt*, Parent of a kindergartener in WVSD1 \\
\hline Andre*, Kindergartener in Video & Ms. Lyle*, Kindergarten teacher in WVSD1 \\
\hline Mariana*, Kindergartener in Video & Ms. Willis*, Kindergarten teacher in WVSD1 \\
\hline Camila*, Kindergartener in Video & Ms. Fletcher*, Kindergarten teacher in WVSD1 \\
\hline Luciana*, Kindergartener in Video & Ms. Pfeiffer*, Kindergarten teacher in WVSD1 \\
\hline Celeste*, Kindergartener in Video & WVSD1 School Principal Anderson \\
\hline Luke*, Kindergartener in Video & Mr. Carey, WVSD1 Curriculum Director* \\
\hline Drakar*, Kindergartener in Video & Ms. Hastings, WVSD1 Kindergarten Liaison* \\
\hline Luis*, Kindergartener in Video & Ms. Beetz*, Parent of a kindergartener in WV School \\
\hline Malia*, Kindergartener in Video & \\
\hline Tommy*, Kindergartener in Video & $\begin{array}{l}\text { Ms. Hildebrand*, Parent of a kindergartener in } \\
\text { WVSD2 }\end{array}$ \\
\hline Javier*, Kindergartener in Video & Ms. Fritz*, Kindergarten teacher in WVSD2 \\
\hline Ruby*, Kindergartener in Video & Ms. Stoddard*, Kindergarten teacher in WVSD2 \\
\hline Joel*, Kindergartener in Video & Ms. Postles*, Kindergarten teacher in WVSD2 \\
\hline Claudia*, Kindergartener in Video & Ms. Binger*, Kindergarten teacher in WVSD2 \\
\hline Maria*, Kindergartener in Video & Ms. Enos*, Kindergarten teacher in WVSD2 \\
\hline Latrell, Kindergartener in Video & WVSD2 School Principal Nye \\
\hline Victor, Kindergartener in Video & Ms. Holgorsen, WVSD2 Curriculum Director \\
\hline Kindergarten Teacher in Video & State Coordinator of Elementary Education \\
\hline Video School (VS) Principal Atwell & State Academic Officer \\
\hline Ms. Jefferson*, Kindergarten Teacher in VS & State Director of Early Learning \\
\hline Ms. Spade*, Kindergarten Teacher in VS & Secretary of Education \\
\hline Ms. Thomas*, Kindergarten Teacher in VS & Former Assistant State Superintendent \\
\hline Ms. Goldstein*, Kindergarten Teacher in VS & WV State School Board Member and Former State \\
\hline Ms. Shires, Literacy Coach for VS & Legislator \\
\hline Ms. Valdes, Bilingual Coordinator* of Video District & WV Senator and Member of Senate Education \\
\hline Mr. Berninger, Literacy Coordinator* of Video District & Committee \\
\hline $\begin{array}{l}\text { Ms. Royal*, Parent of a kindergartener in TX School } \\
\text { District } 1 \text { (TXSD1) }\end{array}$ & $\begin{array}{l}\text { WV Representative and Member of House Education } \\
\text { Committee }\end{array}$ \\
\hline Ms. Knight*, Parent of a kindergartener in TXSD1 & Representative from WV Business Group that Supports \\
\hline Ms. Chan*, Kindergarten teacher in TXSD1 & Public Education \\
\hline Ms. Temple*, Kindergarten teacher in TXSD1 & \\
\hline Ms. New*, Kindergarten teacher in TXSD1 & \\
\hline $\begin{array}{l}\text { Mr. Lewis*, Kindergarten teacher in TXSD1 } \\
\text { TXSD1 School Principal Wetherton }\end{array}$ & \\
\hline Ms. Summers, TXSD1 Assistant Superintendent & \\
\hline $\begin{array}{l}\text { Ms. Welsh*, Parent of a kindergartener in TX School } \\
\text { District } 2 \text { (TXSD2) }\end{array}$ & \\
\hline Ms. Boland*, Parent of a kindergartener in TXSD2 & \\
\hline Ms. Dixon*, Parent of a kindergartener TXSD2 & \\
\hline Ms. Clements*, Parent of a kindergartener TXSD2 & \\
\hline Ms. Johansson*, Kindergarten teacher in TXSD2 & \\
\hline Ms. Barnes*, Kindergarten teacher in TXSD2 & \\
\hline Ms. Patrick*, Kindergarten teacher in TXSD2 & \\
\hline
\end{tabular}


Ms. Walsh*, Kindergarten teacher in TXSD2

TXSD2 School Principal Rogers

Dr. Kennedy*, Assistant Superintendent in TXSD2

Ms. Simmons*, Humanities Coordinator in TXSD2

Mr. Lewis*, Technology Coordinator in TXSD2

Member of TX State Board of Ed

Texas Education Association ECE Person

Texas Education Association Governance Officer

Texas House Member on Education Committee

Lawyer on TX Senate Education Committee

Policy Analyst for TX Senator on Ed Committee

Legislative Director TX Rep on Ed Committee

Senior Advisor to the TX Governor

Director* of Lobbying Group for Children in TX

Legislative lobbyist* for Lobbying Group for Children

in TX

Intern* for Lobbying Group for Children in TX

Representative from State Lobbying Group Supporting

Public Education in TX

Then, across two different school districts in Texas $(n=20)$ and two school districts in West Virginia $(n=17)$, I recruited parents of kindergarteners ${ }^{13}$, kindergarten teachers, and district administrators (see Table 3 for the demographics of each school). The schools and school districts in both states were selected for their typicality within each state and their willingness to participate, which required permission from district administrators, school principals, kindergarten teachers, and families of kindergarteners to be interviewed individually or in focus groups (Merriam \& Tisdell, 2016).

Table $3^{14}$. Demographics for Each Individual School

\begin{tabular}{cccccccccc}
\hline & $\begin{array}{c}\text { Type of } \\
\text { School } \\
\text { Commun- } \\
\text { ity }\end{array}$ & $\begin{array}{c}\text { School } \\
\text { Popula- } \\
\text { tion }\end{array}$ & White & $\begin{array}{c}\text { Afric- } \\
\text { an- } \\
\text { Amer- } \\
\text {-ican }\end{array}$ & $\begin{array}{c}\text { Hisp- } \\
\text { anic }\end{array}$ & Asian & Other & $\begin{array}{c}\text { Free/ } \\
\text { Reduced } \\
\text { Lunch }\end{array}$ & $\begin{array}{c}\text { English } \\
\text { Language } \\
\text { Learner }\end{array}$ \\
\hline TXSD1 & Suburban & 418 & $27 \%$ & $22 \%$ & $41 \%$ & $8 \%$ & $2 \%$ & $46 \%$ & $9 \%$ \\
TXSD2 & Urban & 571 & $71 \%$ & $1 \%$ & $12 \%$ & $13 \%$ & $3 \%$ & $1 \%$ & $4 \%$ \\
WVSD1 & Suburban & 410 & $73 \%$ & $16 \%$ & $1 \%$ & $0 \%$ & $0 \%$ & $58 \%$ & $0 \%$ \\
WVSD2 & Rural & 519 & $97 \%$ & $0 \%$ & $2 \%$ & $0 \%$ & $1 \%$ & $100 \%$ & $0 \%$ \\
$\begin{array}{c}\text { Video } \\
\text { School }\end{array}$ & $\begin{array}{c}\text { Rural/Sub- } \\
\text { urban }\end{array}$ & 380 & $23 \%$ & $12 \%$ & $64 \%$ & $1 \%$ & $0 \%$ & $73 \%$ & $20 \%$ \\
\hline
\end{tabular}

At the state level, I used a snowball-sampling system (Brown, Englehardt, Barry, \& Ku, 2019a; Patton, 2015) to identify key informants who have knowledge about kindergarten and public education issues within their state context. I recruited state administrators, members of policy advocacy organizations, and state policymakers in Texas $(n=12)$ and in West Virginia $(n=9)$.

\subsection{Data Collection}

I collected data for the larger study (Brown, 2021; Brown, Englehardt, Barry, \& Ku, 2019a) for over three years. The process consisted of me interviewing all participants (all names are pseudonyms) after they watched the 23-minute video of a day in the changed kindergarten. I generated memos, observed and took field notes in the kindergarten classrooms of participating kindergarten teachers, and collected artefacts across the multiple context in which this study took place (Adair et al., 2018; Brown, 2021).

${ }^{13}$ While I recognize the term parent can be exclusionary (Brown, Englehardt, Ku, \& Barry, 2019), that is not my intent is using this term. All family members who participated in this study were the biological parents of kindergarteners, but when I use the term parent in this piece, I mean any adult who is responsible for taking care of children enrolled in school.

${ }^{14}$ This table is a modified version of a similar table found in Brown, Englehardt, Barry, and Ku, (2019a) 


\subsubsection{Interviews}

To begin to attain these stakeholders' sensemaking of kindergarten (Brown, Englehardt, Barry, \& Ku, 2019a), I interviewed participants after watching a video of an abbreviated day (23 minutes) in a kindergarten classroom in Texas (Adair \& Kurban, 2019). Tobin et al. (2013) pointed out that responding to such video material is "less daunting" for participants than "being asked to answer abstract questions about ... pedagogical and curricular practices" that define the changed kindergarten; "by providing a common object for attention ... the differences in how people respond to [the video] reveal differences in their beliefs and worldviews" (p. 24).

\subsubsection{A Summary of the Video}

The video provides a coherent narrative capturing each activity 21 children participated in across a day in kindergarten in Texas (Adair \& Kurban, 2019; Brown, Englehardt, Barry, \& Ku, 2019a). It follows the students from their arrival to their departure (Brown, 2021). In that time, the kindergarteners engaged in 14 whole group, teacher-directed learning activities (see Figure 1 for a listing of the academic goals for the week and the schedule of the day for the video).

Figure 1. Weekly Academic Goals and Daily Schedule in the Video ${ }^{15}$

\section{Academic Goals for the Week}

\section{Phonics}

- We will read she, all, and - etc.

- I will read she, all, and —etc.

\section{Reading}

- We will identify different ways the author groups information using text and graphic features.

- I will identify, by myself, where the author used a text or graphic feature to show that something is important.

\section{Writing}

- We will share the sequence of steps to plant a seed.

- I will write the sequence to plant a seed.

Math

- We will identify coins.

- I will name coins and their attributes.

\section{Schedule as it Unfolds Over the Day}

- Arrival, breakfast, and Pledges (7:35-8:05)

- Morning meeting/Calendar (8:05-8:10)

- Phonics, sight words, and phonological awareness (8:10-8:30)

- Poetry (8:30-8:35)

- Morning Message (8:35-8:45)

- Small group word work (8:45-9:00): blue table: Consonant-Vowel-Consonant (CVC) bingo sheet; red table: Lakeshore sentence writing (noun, verb, object); orange table: Word Family Ladder Sheet; green table: Raz Kids on iPads; teacher table: CVC dice-write word.

- Shared Reading and Journal Writing at Tables (9:00-9:45)

- Read to Self and Buddy Reading (9:30-9:50)

- Snack and Bathroom Break (10:00-10:15)

- Whole Groups Math (10:15-10:45)-Counting (days in school, backwards from 20), dot cards, number identification, number comparison, missing number, dimes

15 This figure is a modified version of a similar figure found in Brown, Barry, Ku, and Englehardt (2021). 
- Math Stations (10:45-11:00): blue table: Roll dice, cat in the hat counting hats activity; red table: Pop Addition/Subtraction game; orange table: Shape Pictures: sphere, cylinders, cones, and cubes; green table: iPads; teacher table: graph coins.

- Library (11:05-11:50): Lesson on Plants and Seeds

- $\quad$ Lunch (11:55-12:25)

- Restroom Break (12:25-12:35)

- Science Lab (12:40-1:15) Lesson on Plants and Seeds

- Writing in Science Journal (1:15-1:35)

- $\operatorname{Recess}(1: 45-2: 00)$

- Centers (2:05-2:20): Free choice, finish unfinished work with teacher

- Review, papers, folders, backpacks, dismissal (2:20 -2:35)

- Dismissal (2:35-2:45)

\subsubsection{Interview Protocols}

After watching the video, I interviewed participants using a semi-structured protocol for roughly 45-90 minutes (Merriam \& Tisdell, 2016). I asked participants about their general reactions to the film (Brown. Englehardt, Barry, \& $\mathrm{Ku}, 2019 \mathrm{a}$ ), including such questions as: What about the film did you like, what surprised you, and did it reflect your understanding of kindergarten? They were then asked: How do you think kindergarten prepares children for elementary school? How did or did not the teacher's practices reflect your understanding of teaching kindergarteners? What practices were missing? Which practices in the video do you question or would like to see eliminated from kindergarten? How would you define success in school? How does kindergarten help children achieve such success?

\subsection{Data Analysis}

Similar to my other work (e.g., Brown, Barry, Ku, and Englehardt, 2021), I analysed the data that helped produce this article using traditional qualitative analytic methods as defined by Erickson (1986) and others (e.g., Graue \& Walsh, 1998). This deductive and inductive process included the uploading of transcribed artifacts, interviews, field notes, and memos to Dedoose, a cross-platform data analysis software, coding the data using Dedoose, and analysing the coded data using the constant-comparative method to develop themes that emerged in relation to my research question (Erickson, 1986; Miles et al., 2014).

Through this process (Brown. Englehardt, Barry, \& Ku, 2019a), I developed a potential list of binaries that emerged in relation to my research question (Thomas, 2016). These binaries revealed how familial, education, and political stakeholders made sense of the changed kindergarten in a manner that privileges policymaker's neoliberal reforms (Brown, Englehardt, Barry, \& Ku, 2019b). In the end, I settled on three binaries that capture how these stakeholders did so to provide insight into how policymakers' neoliberal policies that shape the changed kindergarten may be conceptualized otherwise: 'learning for the future vs. for the now,' 'teacher-led vs. student-led learning,' and 'the haves vs. have-nots.'

\section{Results}

\subsection{Learning for the Future vs. for the Now}

A key binary that seemed to emerge in these stakeholders' descriptions of the changed kindergarten was the framing of kindergarten as a place that prepared children to enter the job market and become earners, and ultimately, individualized consumers (Ailwood, 2008) versus an opportunity for children to learn in the here and now. As Ms. Fritz, a parent of kindergartener in WV school district two (WVSD2) stated,

Kindergarten is their one chance to be little because they spend their whole life in school, but, you want them to do well and be successful in school because, in a global world, things are just expanding at such a high level that you just have to keep up.

Ms. Fritz's struggle with the binary view of learning for the future versus the now reflects how policymakers' neoliberal reforms have instilled a logic within education that frames "public school" as being "responsible" for preparing children to be competitive globally so that the students can become part of the "corporate economy as a consumer and as a worker" (Saltman, 2014, p. 252). This focus on the future appears to make it difficult for Ms. Fritz to prioritize children's learning experiences in the here and now. 
The focus on the future for the kindergarten teachers in this study was tied to ensuring children would be competitive in the global economy and prepared for the high-stakes tests that awaited them in later grades. For instance, Ms. Thomas, a kindergarten teacher in the video school, noted,

How kindergarten is framed today is so different; even though we've been schooled it's a journey not a race. However, because there is the state's third grade high-stakes test, everybody has a sort of sense of urgency that you don't want to have, but it's there. You would be a loser teacher if you didn't buy into some of the things that kids need to have at least have heard of if not mastered for first grade, so you feel pressure to get there.

Ms. Enos, a kindergarten teacher in WVSD2, similarly noted the impact of future testing on how she conceptualizes her role as a kindergarten teacher when she said, "What we do starts with testing because you know this testing is looming out there, and then, everything else goes down from that so you have to do this, this, and this to ultimately get ready for the testing." As Spillane (2000) noted, policy environments convey certain messages and connote the culture of schooling, and according to Ms. Thomas and Ms. Enos, policymakers' neoliberal reforms no longer define kindergarten as a "journey." Rather, it is a time to "get ready for the testing," or the children, and their teachers, will be "losers" within the educational system.

Other school personnel expanded this future-oriented understanding of kindergarteners as learners to include their potential as earners and consumers. For instance, Principal Anderson in WVSD1 stated, "I think we're pushing our children in kindergarten so that they are universally competitive. Like, you know, China, Japan. We have to do what we're doing so that they can compete." Principal Wetherton of TXSD1 similarly noted, "We have to prepare our kids to be problem solvers, thinkers, and readers and to function in our school environment. All of this helps them be ready to succeed in the larger community by getting a job and having a career." A Representative from a State Lobbying Group Supporting Public Education in TX also stated, "By offering kindergarten, the state becomes more productive. I think the state in general has better workers, has better parents, better citizens." The Representative from a business group in West Virginia that supports public education also commented, "Kindergarten is the first step to ensure that all students are on a path to be college and career ready." Lastly, a member of the West Virginia legislature who served on the House Education Committee stated,

I just obviously want kindergarten to put them on a trajectory that prepares them to either enter the workforce or to pursue post-secondary education, so just having those skill sets as being necessary for children in order to either pursue either one of those areas is a must.

Combined, these stakeholders' statements reveal how they positioned kindergarten as a part of the "input-output system" that education has become under policymakers' neoliberal reforms; this positioning of learning as "an economic production function" made it difficult for them to place value in the learning that children experience on a day-to-day basis within the confines of the kindergarten classroom (Olssen \& Peters, 2005, p. 324).

\subsection{Teacher-led vs. Student-led Learning}

Another binary that appeared to emerge from these stakeholders' statements about how learning should unfold on a daily basis in the kindergarten classroom (Brown. Englehardt, Barry, \& Ku, 2019a; Brown, Barry, Ku, \& Englehardt, 2021). For example, Ms. Carter, a parent of a kindergartener in WVSD1, stated, "There needs to be a balance in instructional opportunities where children are taking the lead and adults are supporting them and other experiences where teachers are taking the lead, but the children aren't passive." Ms. Royal, a parent of a kindergartener in TXSD1 also noted,

One thing that does worry me a little bit is, are we giving them enough time and freedom in the classroom to figure out who they are as little humans? Or, are we very much focused on developing or cultivating skills that work well in a corporate environment, especially since the economy has moved from production to service. Are we just encouraging kids to learn how to listen and to be obedient?

These parents' statements begin to illuminate the binary between teacher-led and student-led learning, which positions the kindergarten teachers as "the holders of important knowledge" (Kocher \& Pacini-Ketchabaw, 2011, p. 49) and students as the receivers of that "important knowledge."

While many of the stakeholders in this study recognized that teacher-led learning was prioritized in kindergarten, they appeared uncomfortable with this framing of instruction. For example, Ms. Clements, a parent of a kindergartener TXSD2, noted, "The success of a kindergartener is defined by how much can they read and write at the end of the year." This led her to add, "Social skills are no longer a focus. The kids are very book smart, but they don't have a whole lot of problem-solving skills on how to get along and cope." Ms. Postles, a kindergarten teacher in WVSD2, relatedly stated, "We are doing children a disservice because we have all these kids who know the letters, their sounds, and the numbers, but they don't know how to get along with each other. They can't solve their own problems." Ms. Binger, Ms. Postles's 
colleague, added, "They learn that through play, but I don't think they play enough."

Lastly, in identifying this tension that emerges in this binary between teacher and student-led learning, Ms. Knight, a parent of a kindergartener in TXSD1 stated, "It's important for kids to understand they have the option to make choices, but academics are constantly being shoved down their throats." Across these statements, these stakeholders appeared to be seeking out a balance of learning experiences for children, which the kindergarteners in the video classroom also appeared to want. For example, Andre noted, "I like going to centres because we can play and we can do anything." Willow added, "Yeah, I would like more time to play with my friends in our class," and Maria José commented, "And, we get to play with our friends. I love playing with my friends." However, for these kindergarten teachers and parents, they appeared to recognize that the dominant neoliberal focus of schooling produces a binary of instruction that is rooted in a "prevailing discourse" that "insists" children become "entrepreneurs" that possess a specific set of "cognitive and symbolic capital" needed to succeed in school and society at large (De Lissovoy, 2018, p. 202). Such skills are provided to children through teacher-directed instruction, illuminating to students and their families the skills and knowledge that are valued within this framing of schooling (McNeil, 2000) and ensuring the students receive such learning experiences (Brown, 2021).

While there appeared to be a desire by these stakeholders for balance in the learning experiences that could provide children with more student-led instruction (Brown, Barry, Ku, \& Englehardt, 2021), Ms. Atwell, the principal of the school in my video, noted that finding balance within teachers' instruction is difficult because there is so much pressure on children to perform academically. This principal stated,

It's a constant struggle for teachers to balance their instruction because the pressure to perform. There's a lot of pressure on kids. There's a lot of pressure on teachers. There's a lot of pressure on administrators. It's just a lot to have these kids ready for the tests in third grade.

Yet, ultimately, as the State Academic Officer in West Virginia noted, this "pressure" to perform leads kindergarten teachers to enact "a watered-down approach of the third-grade test," which, as Principal Rogers in TXSD2 noted, leads to "a reduction in playtime and increase in drill and kill activities that will replicate what's going to happen on the test rather than authentic learning, real life learning experiences." Ms. Hologorsen, the Curriculum Director for WVSD2, summarized this tension that emerges when teacher-led learning is privileged over child-led learning when she stated,

In kindergarten, I think there needs to be a lot of hands on group work, collaboration, not a lot of seat work, worksheets, and so on. I think we're having a hard time reconciling that against the standards that we're required to teach. I'm having a really hard time figuring out, 'What's the best way of making sure our kids master these standards that we're being held accountable for at the same time making sure that there is a lot of student-led inquiry?' But, I just don't know. I'm stuck.

Lipman (2013) argued the "strength of accountability discourses" (p. 569) are clearly marked through the standards and the high-stakes standardized tests that await kindergarteners in the later grades (Brown, 2021). In their statements, these stakeholders continue "to work discursively to shape educational discourse and teacher practices and subjectivities" in a manner that reinforces and privileges kindergarten teachers to be engaged in - and school administrators to emphasize the use of teacher-directed over child-directed learning experiences (p. 558).

\subsection{The Haves vs. Have Nots}

Alongside these two binaries seemed to be a consistent reference by stakeholders to students who have vs. have not. This division of students was often framed though the economic lens that defines neoliberalism (Apple, 2001). For instance, the State Coordinator of Elementary Education in West Virginia commented,

Kindergarten gives a lot of children access to some enriching experiences that they probably don't have simply because so much of our state is in poverty; they don't have a lot of access to texts. Once they get into school, they have more access to resources and books.

The Texas Education Association ECE Person similarly commented, "When I look at breaking the cycle of poverty, which over $50 \%$ of the children in our state live in, I look at education. If you educate a child well, then we have that opportunity to break that cycle." Furthermore, a WV Senator and member of the Education Committee stated

"Kindergarten is the first step in reducing the achievement gap in students from different socio-economic backgrounds." All three statements reflect an underlying belief within neoliberalism that poverty correlates with children who are often framed as damaged (Tuck, 2009) and also powerless without the intervention of schooling (De Lissovoy, 2012). As Slater (2015) noted, "education" becomes "the ideal mechanism of recovery" for those who have not (p. 3).

Such deficit understandings of those students who 'have not' were also associated with children's academic skills (Brown, 2008a; Nxumalo \& Adair, 2019). For instance, Dr. Kennedy, the Assistant Superintendent in TXSD2 noted, 
There is so much pressure to cover content, and when you look at the TEKS [the state content standards] in kindergarten, children have to come in with a base set of knowledge and skills, and when they don't because they are coming in as English language learners or coming out of poverty, the teacher has to back-fill and scaffold and do all that sort of thing before she can even get to the TEKS. And that is why time is so critical; the teacher needs twice as much time to catch the kids up.

For this Assistant Superintendent, the 'have nots' need more schooling experiences to gain the skills and knowledge needed for success. Yet, because "the teacher needs twice as much time to catch the kids up," it appears for this Superintendent as if these students never meet grade expectations.

Ms. Postles, a kindergarten teacher in WVSD2, echoed this assistant superintendent's sentiment when she stated, "If we don't get done what needs to be done in kindergarten, the kids will be even further behind in first grade. And if that's not made up in first grade, they'll go into second grade even further behind." Furthermore, Ms. Beetz, a parent of a kindergartener in WVSD2 commented,

The school system has such high expectations, which I think we should have. But, I'm not sure it's set up to help those kids who don't grasp it. Sometimes kids fall behind. It just happens. It's the way our system works. If they don't get it when they're taught it, it's hard for them to keep up, and the teachers don't have that breathing room to go back to help these kids who didn't get it. I know that sounds harsh. The system is harsh. They don't have time to go back over it in first grade. If you're not reading when you get there, you're behind. When you get to second grade, you're reading more, and nobody goes back and helps you.

Ms. Boland, a parent of a kindergartner in TXSD2, analogously remarked,

When kids don't achieve at that mastery level on their kindergarten report cards, it negatively affects the children because they're going to inevitably feel like they're not meeting the standard somehow--and this starts a negative cycle, which is much more detrimental than whether they could read on grade level. It's a whole day of feeling like you're not meeting the standards, that you're less than.

Combined, these administrators, teachers, and parents are framing what it means to be a kindergartener for those who 'have not' through Ball's (2003) notion of double alienation, particularly when viewing their framing of the 'have nots' through the binary of 'teacher-led vs. student-led learning.' In these stakeholders' statements, the students who 'have not' are alienated from being seen as worthy of the learning experiences that many of these stakeholders would like them to have in kindergarten because they have to catch up to policymakers' academic achievement expectations (e.g., Brown, Barry, Ku, \& Englehardt, 2021). Thus, most kindergarteners across these two states are or will be viewed as lacking. As such, they will require teacher-directed instruction to prepare them to be the kind of learners who can become future earners and consumers as determined by a series of test scores (Ailwood, 2008; Brown, 2021; Brown, Englehardt, Barry, $\& \mathrm{Ku}, 2019 \mathrm{~b})$.

\section{Discussion}

The three binaries the stakeholders in this article appeared to employ to describe the changed kindergarten illuminate how policymakers' neoliberal education policies define "the possible field of action" (Foucault, 1982, p. 790) for this program. Policymakers' reforms seemed to lead these stakeholders to frame kindergarten as an input-output system that privileges teacher-directed learning experiences and positions many children as not being worth of other forms of instruction (Ball 2003; Lipman, 2013; Olssen \& Peters, 2005). Such binaries reduce kindergarten to "a tool of the state for self-regulation and self-governance of its citizens, rather than an exclusive part of the emancipatory project" that many within early education hope and want it to be (Clark \& Richards 2017, p. 135). Thus, to generate new "fields of action' requires that these binaries be dismantled (Foucault, 1982; Mac Naughton, 2005).

\section{Implications}

I contend that to disassemble what I termed 'learning for the future' over 'learning for the now' binary would require that education stakeholders work collectively to reframe the focus of public education from an individualized perspective to a community-based perspective (e.g., Clark \& Richards, 2017). By prioritizing the future, education stakeholders seemed to center their understanding of schooling on the production and consumption of "the individual [which] breaks his links with others, splits up community life, forces the individual back on himself, and ties him to his own identity in a constraining way" (Foucault, 1982, p. 781). Meaning, the value of students' future test scores, incomes, or consumption should be replaced with a currency that prioritizes their ability to participate within a democratic classroom in the here and now (Apple, 2001; Brown, 2021). This would entail the dominant, technocratic view of teaching, learning, and assessment be replaced with what Moss (2017) termed teaching rooted in "experimentation" to allow teachers and kindergarteners to work "on a diversity of projects inspired by different ideas, desires and circumstances" (p. 24). This "social or relational model" of democratic learning emphasizes "relationships with others" 
and challenges the neoliberal "individualized concept" of learning that promotes "self-interest and individual choice" (Clark \& Richards 2017, p. 135).

To be clear, such a vision of schooling does not eliminate the 'future' from the education equation (Brown, 2021; Uprichard, 2008). Rather, it requires a re-envisioning of schooling from an outcomes-based process to an amplification process in which all children continuously grow within the learning community year after year as citizens within their communities that exist in and outside of school (Brown, Barry, \& Ku 2021).

Such a vision of learning and of schooling might be challenged and possibly rejected by various stakeholders (e.g., Adair et al., 2018) because, as Foucault (2008) noted, the neoliberal system of governance "play[s] a regulatory role at every moment and every point in society" (p. 145). Still, education stakeholders must recognize that "power is exercised only over free subjects," which means that "individual or collective subjects ... are faced with a field of possibilities in which several ways of behaving, several reactions and diverse comportments, may be realized" (p. 790). By recognizing this "field of possibilities," education stakeholders can begin to see that they are capable of resisting policymakers' neoliberal reforms in ways that subverts this binary (Mac Naughton, 2005) and makes visible the contemporaneous value of kindergarten to kindergarteners in the here and now, themselves, and other education stakeholders (Brown, Englehardt, Barry, \& Ku, 2019b). Moreover, by re-centering stakeholders' conceptions of teaching and learning in the now, what occurs on a moment-to-moment basis becomes of critical importance (Brown, Barry, $\mathrm{Ku}, \&$ Englehardt, 2021). This leads to the second binary that emerged in my data analysis process and reveals the intersectionality (Collins, 2000) of the binaries produced by policymakers' neoliberal education reforms.

To upend what I termed the 'teacher-led' versus 'student-led' learning binary in the kindergarten classrooms requires the (re)purposing of instruction to be fostering an interdependent community of learners (Brown et al., 2018). Prioritizing the needs of the learning community rather than the individual student or teacher breaks the "barrier of knowledge" that results from policymakers' neoliberal reforms by moving "beyond the Western epistemological canon," and instead, centres the curriculum, instruction, and assessment on the immediate needs of the learners, their families, and the teacher within the classroom community (Fregoso Bailón \& De Lissovoy, 2019, p. 359).

I recognize that simply stating rather than taking actionable measures towards shifting the focus of instruction in kindergarten classrooms to the needs of the community can lead to a (re)inscribing of the dominant, western, White male perspectives about teaching and learning (Cannella, 1997; Pérez, 2019). Thus, instruction should be viewed as a communal and complex process that emerges from dialogic interaction between teachers and students without prioritizing the needs of any one member of the community over another. Such a shift would require education stakeholders to value the intellectual development of all children, their families, and the classroom teacher and to seek out "alternative channels of knowledge" that project varied ways of knowing (Fregoso Bailón \& De Lissovoy, 2019, p. 366).

By pivoting instruction off the needs of the immediate learning community, education stakeholders need to recognize that any form of curriculum, teaching, and/or assessment is not only "mind-altering" but also of intellectual value (Eisner, 1997, p. 349). Whereby, as Ladson-Billings (2016) suggested, generating a curriculum based on "the experiences of the learners" within the immediate classroom environment requires a "fluid and changing" framing of the learning process (p. 104). Thus, to overturn this instructional binary, classroom teachers and other education stakeholders should possess a "neoliberal literacy" (Loh \& Hu, 2014, p. 20) so that they can speak back to policymakers' demands for specific forms of instruction (Brown, Barry, $\mathrm{Ku}, \&$ Englehardt, 2021) through communal practices that lead to "more democratic definitions of education that are being currently pushed out, and to open up new and more ethical questions" (Stevenson, 2010, p. 356). Engaging in such community-based practices hold promise to redefine the purpose and process of kindergarten so that the learning in the now is prioritized, and pedagogical practices are rooted in learning experiences that mirror the sociocultural worlds of all community members within every kindergarten class (Pérez, 2019).

Lastly, to dismantle what I termed the prioritization of the 'haves' over the 'have-nots' requires education stakeholders to first illuminate how the current framing of schooling in the US "is characterized by a condition of instability, precariousness, and risk" (De Lissovoy, 2018, p. 191). According to Lewis (2018), the insecurities embedded in policymakers' neoliberal reforms reflect "the latest iteration of colonialism and imperialism with revamped forms of oppression, systemic structures of racism and marginalization" (p. 67). Meaning, these neoliberal policies produced these "conditions of vulnerability and disparity" that not only eliminate particular acts of schooling but also the 'have-nots' and their histories within this process of schooling (Grande, 2018, p. 169). Thus, by prioritizing those who have been labelled as 'have nots,' the "erasures, displacements and exclusions" that are "normalized in everyday encounters" of schooling may be revealed (Nxumalo, 2016, p. 643). Such revelations not only challenge the "systemic inequality and marginalization" that has accelerated under these neoliberal reforms, but they also create the space to 
question these assumptions (De Lissovoy, 2016, p. 353).

Practically speaking, to rupture this binary would require school stakeholders to put the histories and tellings of the 'have nots' to the frontline of the curriculum (Lane, 2018; Pérez, 2019), which would "be different and unique to each setting and spatial location in relation to the unique power relations embedded within each space" (Eizadriad, 2019, p. 203). As I have argued elsewhere (e.g., Brown, 2021), this would necessitate that classroom teachers engage in such acts as counterstories (Delgado, 1989; Osorio, 2018), storytelling from ancestors (Grande, 2018), or engaging in poetry from the children's' sociocultural worlds (Fregoso Bailón \& De Lissovoy, p. 2019).

Such practices, alongside reframing classroom instruction as a communal process, allow the funds of knowledge children and their families bring to school to become the foundation of the curriculum being employed in the classroom (Moll et al., 1992). Furthermore, it would require a rethinking about the metrics used to measure the learning of the 'have nots' so that the neoliberal logic of schooling can be dismantled (Fogarty et al., 2017). Engaging in these actions that seek to dismantle this binary could reposition all children, families, and communities as knowledgeable and capable, thereby eliminating the notion that certain children, families, and communities are lacking/'have not' (Brown, 2008a; Nxumalo and Adair 2019).

To counter these or any binary that exists within the current neoliberal framing of schooling within the US and across the globe also requires political action (Brown, 2021; Brown, 2008b), which necessitates the building of alliances across education communities (Apple, 2001; Moss, 2017). By becoming "agents of democracy" (Meier, 2000, p. 17) who work collectively to "push-back" against the "common sense" that emerges in the binaries generated through policymakers' neoliberal reforms (Gatti \& Catalano, 2015, p. 157), the goal for education stakeholders would be to foster schooling process that actively engages all members of the school community "in everyday practices of resurgence" that center the learning experiences occurring in kindergarten classrooms on children and their families (Corntassel, 2012, p. 89).

As Gerrard (2015) pointed out, there is much difficulty in resisting the "centrifugal force of contemporary politics, which constantly pulls debate towards the primary concern of what is administratively possible under neoliberal capitalism" (p. 866). Thus, whatever changes may emerge from any process of disruption, as Evans (2016) poignantly stated, public education stakeholders must "maintain a stance of constant critical questioning, never allowing ourselves to be too comfortable with the landscape we create, or for our practices and understandings to become taken for granted as part of the status quo" (p. 75). To remain critical while being uncomfortable with whatever emerges from these proposed acts of change will require education stakeholders to question constantly how their proposed curricula and forms of instruction might privilege one group and disenfranchise another at any step in the reform process (Cannella, 1997; Pérez, 2019).

\subsection{Conclusion}

The vigilance and political action I outline in the above and contend are necessary to dismantle policymakers' neoliberal reforms may create opportunities for schooling experiences infused with beliefs in the inherent value of all students learning in the now so that they become active democratic citizens as they progress through and beyond the education system (Brown, Englehardt, Barry, \& Ku, 2019b; Brown, Barry, \& Ku, 2021). Furthermore, I contend that finding and capitalizing on the inherent value of community-based acts of inquiry within each classroom and devaluing the power of mandated curricula and assessments may lead to a range of instructional practices that neoliberal reforms have eliminated from most public education systems (Brown et al., 2018). Finally, I argued that seeking out and capitalizing on the funds of knowledge all students bring to the kindergarten classroom (Moll et al., 1992) could eliminate the binary of the 'haves' and 'have nots' within classrooms. Combined, such actions may begin to pull apart the neoliberal discourses that define the changed kindergarten specifically and public education in general so that education stakeholders can begin to reframe the purpose and process of schooling and what it means for a child to become educated around more democratic principles.

\section{Acknowledgements}

The author would like to thank the Spencer Foundation Small Grants Program (Reference \# 201700116) and the Big XII Faculty Fellowship Program for their support of this study.

He would also like to thank Dr. David P. Barry, Da Hei Ku, Dr. Joanna Englehardt, Dr. Jennifer Keys Adair, Dr. Melissa Sherfinski, Natalie Weber, Hye Ryung Won, Dr. Karen French, and Robert Donald for their assistance in conducting this study.

\section{References}

Adair, J. K., Colgrove, K. S. S., \& McManus, M. E. (2018). Troubling messages: Agency and learning in the early schooling experiences of children of Latinx immigrants. Teachers College Record, 120, 1-40. 
Adair, J. K., \& Kurban, F. (2019). Video-cued ethnographic data collection as a tool toward participant voice. Anthropology and Education Quarterly, 50, 312-332. https://doi.org/10.1111/aeq.12305

Ailwood, J. (2008). Learning or earning in the 'smart state': Changing tactics for governing early childhood. Childhood, 15, 535-551. https://doi.org/10.1177/0907568208097206

Apple, M. W. (2001). Educating the 'Right'Way: markets, standards, God, and inequity. RoutledgeFalmer.

Ball, S. J. (2007). Education plc: Understanding private sector participation in public sector education. Routledge. https://doi.org/10.4324/9780203964200

Bassok D., Latham, S., \& Rorem, A. (2016). Is Kindergarten the new first grade? AERA Open, 1, 1-31. https://doi.org/10.1177/2332858415616358

Biesta, G. (2006). What's the point of lifelong learning if lifelong learning has no point? On the democratic deficit of policies for lifelong learning. European Educational Research Journal, 5, 169-180. https://doi.org/10.2304/eerj.2006.5.3.169

Brown, C. P. (2008a). Examining how the students "determines" the success and/or failure of education reform. International Critical Childhood Policy Studies, 1(1), 1-27.

Brown, C. P. (2008b). Research in Review: advocating for policies to improve practice. Young Children, 63(4), 70-77.

Brown, C. P. (2015). Taking and teaching the test are not the same: A case study of first year teachers' experiences in high-stakes contexts. Teachers and Teaching: Theory and Practice, 21(8), 1026-1044. https://doi.org/10.1080/13540602.2015.1005870

Brown, C. P. (2021). Resisting the kinder-race: Restoring joy to early learning. Teachers College Press.

Brown, C. P., \& Barry, D. P. (2019). Public policy and early childhood curriculum in the United States. In J. J. Mueller $\&$ N. File (Eds.). Curriculum in early childhood: re-examined, reclaimed, and renewed, $2^{\text {nd }}$ ed. (pp. 17-33). Routledge.

Brown, C. P., Barry, D., \& Ku, D. (2021). How education stakeholders made sense of school readiness in and beyond kindergarten. Journal of Research in Childhood Education, 35(1) 122-142. https://doi.org/10.4324/9781315103310-2

Brown, C. P., Barry, D., \& Ku, D., \& Englehardt, J. (2021). How education stakeholders made sense of the types of learning experiences children are and should be having in kindergarten and why. Early Education and Development, 32(2), 291-322. https://doi.org/10.1080/10409289.2020.1750292

Brown, C. P., Englehardt, J., Barry, D. P., \& Ku, D. (2019a). Examining how stakeholders at the local, state, and national level made sense of the changed kindergarten. American Educational Research Journal, 56 (3), 822-867.

Brown, C. P., Englehardt, J., Barry, D., \& Ku, D. (2019b). Questioning democratic notions of governance: A case study examining how a kindergarten teacher and her students give voice to and enact a neoliberal framing of schooling. Contemporary Issues in Early Childhood, 20(3), 236-252.

Brown, C. P., Englehardt, J., Ku, D. \& Barry, D. P. (2019c). "Where's the joy in the classroom?”: Families' sensemaking of the changed kindergarten. The Elementary School Journal, 120(2), 319-346. https://doi.org/10.1086/705964

Brown, C. P., Feger, B. S., \& Mowry, B. N. (2018). RIGOROUS DAP in the early years: From theory to practice. Redleaf Press.

Cannella, G. (1997). Deconstructing early childhood education: Social justice and revolution. Peter Lang.

Clark, J., \& Richards, S. (2017). The cherished conceits of research with children: Does seeking the agentic voice of the child through participatory methods delivers what it promises? Sociological Studies of Children and Youth, 22, 127-147. https://doi.org/10.1108/S1537-466120180000022007

Collins, P. H. (2000). Black feminist thought: Knowledge, consciousness, and the politics of Empowerment. 2nd ed. Routledge.

Corntassel, J. (2012). Re-envisioning resurgence: Indigenous pathways to decolonization and sustainable self-determination. Decolonization: Indigeneity, Education \& Society, 1, 86-101.

Dahlberg, G., \& Moss, P. (2005). Ethics and politics in early childhood education. Routledge Falmer.

De Lissovoy, N. (2014). Pedagogy of the impossible: Neoliberalism and the ideology of accountability. Policy Futures in Education, 11, 423-435. https://doi.org/10.4324/9780203980583 
De Lissovoy, N. (2015). Neoliberalism and the contradictions of freedom: Ideology, subjectivity, and critical pedagogy. Texas Education Review, 3, 44-54. https://doi.org/10.1080/02680939.2017.1352031

De Lissovoy, N. (2018). Pedagogy of the anxious: Rethinking critical pedagogy in the context of neoliberal autonomy and responsibilization. Journal of Education Policy, 33, 187-205.

Delgado, R. (1989). Storytelling for oppositionists and others: A plea for narrative. Michigan Law Review, 87, 2411-2441. https://doi.org/10.2307/1289308

Dombkowski, K. (2001). Will the real kindergarten please stand up? Defining and redefining the twentieth-century US kindergarten. History of Education, 30, 527-545. https://doi.org/10.1080/00467600110064762

Erickson, F. (1986). Qualitative methods in research on teaching. In M. Whittrock (Ed.), Handbook on research on teaching, 119-161. Macmillan.

Evans, K. (2016). Beyond a logic of quality: Opening space for material-discursive practices of 'readiness' in early years education. Contemporary Issues in Early Childhood, 17, 65-77. https://doi.org/10.1177/1463949115627904

Fogarty, W., Riddle, S., Lovell, M., \& Wilson, B. (2017). Indigenous education and literacy policy in Australia: Bringing learning back to the debate. The Australian Journal of Indigenous Education, 47(2), 185-197.

Foucault, M. (1982). The subject and power. Critical Inquiry, 8, 777-795. https://doi.org/10.1086/448181

Foucault, M. (2008). The birth of biopolitics: Lectures at the Collège de France, 1978-1979. (trans. by Graham Burchell). Palgrave Macmillan.

Fregoso Bailón, R. O., \& De Lissovoy, N. (2019). Against coloniality: Toward an epistemically insurgent curriculum. Policy Futures in Education 17, 355-369. https://doi.org/10.1177/1478210318819206

Gerrard, J. (2015). Public education in neoliberal times: Memory and desire. Journal of Education Policy, 30, 855-868. https://doi.org/10.1080/02680939.2015.1044568

Grande, S. (2018). Aging, precarity, and the struggle for Indigenous elsewhere. International Journal of Qualitative Studies in Education, 31, 168-176. https://doi.org/10.1080/09518398.2017.1401145

Graue, E. (2009). Reimagining kindergarten. The School Administrator, 66, 10-15.

Graue, M. E., \& Walsh, D. J. (1998). Studying children in context: Theories, methods, and ethics. Sage.

Kocher, L., \& Pacini-Ketchabaw, V. (2011). Destabilizing binaries in early childhood education: The possibilities of pedagogical documentation. In Beyond binaries in education research, edited by W. Migley, M. A. Tyler, P. A. Danaher, and A. Mander, 46-58. Routledge.

Lane, T. M. (2018). The frontline of refusal: indigenous women warriors of standing rock. International Journal of Qualitative Studies in Education, 31, 197-214. https://doi.org/10.1080/09518398.2017.1401151

Lemke, T. (2001). 'The birth of bio-politics': Michel Foucault's lecture at the Collège de France on neo-liberal governmentality, Economy and Society, 30, 190-207. https://doi.org/10.1080/03085140120042271

Lipman, P. (2013). Economic crisis, accountability, and the state's coercive assault on public education in the USA. Journal of Education Policy, 28, 557-573. https://doi.org/10.1080/02680939.2012.758816

Loh, J., \& Hu, G. (2014). Subdued by the system: Neoliberalism and the beginning teacher. Teaching and Teacher Education, 41, 14-21. https://doi.org/10.1016/j.tate.2014.03.005

Mac Naughton, G. (2005). Doing Foucault in early childhood studies: Applying post-structural ideas. Routledge. https://doi.org/10.4324/9780203465332

McNeil, L. M. (2000). Contradictions of school reform: Educational costs of standardized testing. Routledge.

Merriam, S. B., \& Tisdell, E. J. (2016). Qualitative research: A guide to design and implementation. $4^{\text {th }}$ ed. Jossey-Bass.

Miles, M. B., Huberman, A. M., \& Saldaña, J. (2014). Qualitative data analysis: A methods sourcebook $3^{\text {rd }}$ ed. Sage.

Moll, L. C., Amanti, C., Neff, D., \& González, N. (1992). Funds of knowledge for teaching: Using a qualitative approach to connect homes and classrooms. Theory into Practice, 31, 132-141.

Moss, P. (2014), Transformative change and real utopias in early childhood education. Routledge. https://doi.org/10.4324/9781315779904

Moss, P. (2017). Power and resistance in early childhood education: From dominant discourse to democratic experimentalism. Journal of Pedagogy, 8, 11-32. https://doi.org/10.1515/jped-2017-0001 
Nxumalo, F. (2016). Towards 'refiguring presences' as an anti-colonial orientation to research in early childhood studies. International Journal of Qualitative Studies in Education, 29, 640-654. https://doi.org/10.1080/09518398.2016.1139212

Nxumalo, F., \& Adair, J. A. (2019). Social justice and equity in early childhood education. In Wiley handbook of early childhood care and education, edited by C. P. Brown, M. McMullen, \& N. File, 661-681. Wiley Blackwell. https://doi.org/10.1002/9781119148104.ch29

Olssen, M., \& Peters, M. A. (2005). Neoliberalism, higher education and the knowledge economy: From the free market to knowledge capitalism. Journal of Education Policy 20, 313-45. https://doi.org/10.1080/02680930500108718

Osorio, S. L. (2018). Border stories: using critical race and Latino critical theories to understand the experiences of Latino/a children. Race, Ethnicity, and Education, 21, 92-104.

Patton, M. Q. (2015). Qualitative research and evaluation methods (4 ${ }^{\text {th }}$ ed.). Sage

Pérez, M. S. (2019). Dismantling racialized discourses in early childhood education and care: A revolution towards reframing the field. In Disrupting and countering deficits in early childhood education, edited by F. Nxumalo \& C. P. Brown, 20-36. Routledge. https://doi.org/10.4324/9781315102696-2

Rose, N. (1996). Governing "advanced" liberal democracies. In Foucault and political reason: liberalism, neo-liberalism, and rationalities of government, edited by A. Barry, T. Osborne, \& N. Rose, 37-64. University of Chicago Press.

Saltman, K. J. (2014). Neoliberalism and corporate school reform: "Failure" and "creative destruction". Review of Education, Pedagogy, and Cultural Studies, 36, 249-259. https://doi.org/10.4324/9781315634678

Slater, G. B. (2015). Education as recovery: Neoliberalism, school reform, and the politics of crisis. Journal of Education Policy, 30, 1-20.

Spillane, J. P. (2000). Cognition and policy implementation: District policymakers and the reform of mathematics education. Cognition and Instruction, 18, 141-179. https://doi.org/10.1207/S1532690XCI1802_01

Thomas, G. (2016). How to do your case study (2 ${ }^{\text {nd }}$ ed.). Sage.

Tobin, J., Arzubiaga, A. E., \& Adair, J. K. (2013). Children crossing borders: Immigrant parent and teacher perspectives on preschool. Russell Sage Foundation.

Tobin, J., Hseuh, Y., \& Karasawa, M. (2009). Preschool in three cultures Revisited China, Japan, and the United States. The University of Chicago Press. https://doi.org/10.7208/chicago/9780226805054.001.0001

Tuck, E. (2009). Suspending damage: A letter to communities. Harvard Educational Review, 79, 409-427. https://doi.org/10.17763/haer.79.3.n0016675661t3n15

Uprichard, E. (2008). Children as 'being and becomings': Children, childhood and temporality. Children in Society, 22, 303-313. https://doi.org/10.1111/j.1099-0860.2007.00110.x

\section{Copyrights}

Copyright for this article is retained by the author(s), with first publication rights granted to the journal.

This is an open-access article distributed under the terms and conditions of the Creative Commons Attribution license which permits unrestricted use, distribution, and reproduction in any medium, provided the original work is properly cited. 